\title{
Skating Toward Deregulation: Canadian Developments
}

Timothy J. Brennan

University of Maryland-Baltimore County

Follow this and additional works at: https://www.repository.law.indiana.edu/fclj

Part of the Administrative Law Commons, Antitrust and Trade Regulation Commons, Communications Law Commons, Comparative and Foreign Law Commons, and the Consumer Protection Law Commons

\section{Recommended Citation}

Brennan, Timothy J. (2008) "Skating Toward Deregulation: Canadian Developments," Federal Communications Law Journal: Vol. 60 : Iss. 2 , Article 5.

Available at: https://www.repository.law.indiana.edu/fclj/vol60/iss2/5

This Article is brought to you for free and open access by the Law School Journals at Digital Repository @ Maurer Law. It has been accepted for inclusion in Federal Communications Law Journal by an authorized editor of Digital Repository @ Maurer Law. For more information, please contact rvaughan@indiana.edu.

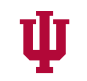

JEROME HALL LAW LIBRARY INDIANA UNIVERSITY Maurer School of Law
Bloomington 


\section{Skating Toward Deregulation: Canadian Developments}

\section{Timothy J. Brennan*}

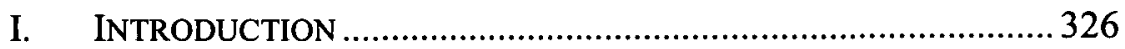

II. THE CRTC FORBEARANCE PROCEEDINGS .............................. 329

A. Local Telephone Service ............................................... 329

B. VoIP Forbearance ................................................. 333

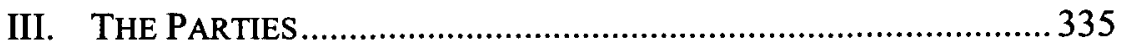

A. Industry Participants ................................................... 335

B. Telecommunications Policy Review Panel ..................... 338

C. Competition Bureau...................................................... 340

IV. THE GOVERNOR IN COUNCIL CUTS TO THE CHASE.................. 344

V. ECONOMIC COMMENTS AND CRITIQUES …...............................346

A. Regulation Within Markets .......................................... 346

B. $\quad$ Measuring Potential Share ............................................. 346

C. Service Market Definition............................................ 347

D. Geographic Market Definition....................................... 348

E. Share Tests and Strategic Responses............................ 350

F. $\quad$ Targeted Low Prices.................................................... 351

\footnotetext{
* Professor of Public Policy and Economics, University of Maryland-Baltimore County. Ph.D., M.A., M.A., University of Wisconsin; B.A., University of Maryland. The author became familiar with these issues while serving the Canadian Competition Bureau as a consultant on telecommunications policy during the last part of 2005 and as the T.D. MacDonald Chair in Industrial Economics during 2006. Without implying agreement, he thanks Patricia Brady, Jeff Church, Randall Hofley, Patrick Hughes, David Krause, and David Teal for particularly informative discussions. The opinions expressed here are solely his and not those of the Bureau or any of its staff. The author also thanks Fred Barney, Victor Glass, Tim Tardiff, and other participants in the Rutgers University Center for Research in Regulated Industries 26th Annual Eastern Workshop on Advanced Regulatory Economics.
} 


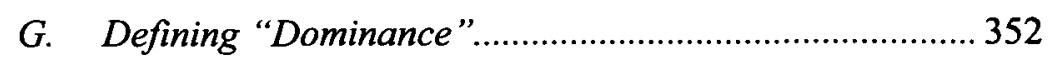

H. Building Access........................................................ 353

I. Timing of Intervention .............................................. 354

J. Regulated Conduct................................................... 355

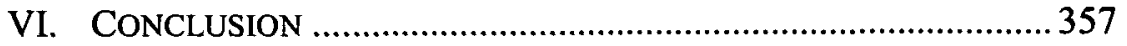

\section{INTRODUCTION}

Despite extensive deregulation in the telecommunications sector, local voice service has proven to be the last and most difficult market to deregulate. Perhaps the most extensive steps toward deregulation of this last stage are being taken in Canada. In April 2006, the Canada RadioTelevision and Telecommunications Commission ("CRTC") decided it was "prepared to forbear" from regulating the local voice service provided by the incumbent local exchange carrier ("ILEC"), if the ILEC could show it had lost twenty-five percent of its share in a relevant market defined by both product (including voice-over Internet protocol or "VoIP", excluding wireless) and geography (primarily the census metropolitan area or "CMA"). ${ }^{1}$ ILECs were also prohibited from efforts to "winback" customers who had switched to competitors in the prior three months, unless the ILEC had lost twenty percent of its market. ${ }^{2}$ This decision followed a 2005 CRTC decision not to deregulate ILEC VoIP service. ${ }^{3}$

The CRTC did not have the last word. Shortly after its local forbearance decision, the Cabinet Ministers, referred to in Canada as the Governor in Council ${ }^{4}$ of the recently established conservative government, issued an "Order in Council" requesting that the CRTC reconsider its VoIP decision. ${ }^{5}$ The CRTC declined to forbear, claiming that VoIP was in the same market as regular voice service, which it was also refusing to forbear,

1. Forbearance from the regulation of retail local exchange services, Telecom Decision, Can. Radio-Television \& Telecomm. Comm'n [CRTC] 2006-15, paras. 242, 49, 62, 158 (Apr. 6, 2006) (Can.) [hereinafter Local Decision], available at http://www.crtc.gc.ca/ archive/ENG/Decisions/2006/dt2006-15.htm.

2. Id. at para. 488 .

3. Regulatory framework for voice communication services using Internet Protocol, Telecom Decision, CRTC 2005-28, para. 193 (May 12, 2005) [hereinafter VoIP Forbearance], available at $\mathrm{http} / / \mathrm{www} . c r t c . g c . c a /$ archive/ENG/Decisions/2005/dt2005-28.htm.

4. Formally, the decision comes from the Govemor General, the representative of the British monarchy in Canada, which is still a member of the Commonwealth. However, all effective governing authority rests with Parliament, from which the Prime Minister and his Cabinet come.

5. Order of the Governor in Council, P.C. 2006-305 (Can.), as reprinted in Reconsideration of Regulatory framework for voice communication services using Internet Protocol, Telecom Public Notice, CRTC 2006-6 app. (May 6, 2006) [hereinafter VoIP Notice], available at http://www.crtc.gc.ca/archive/ENG/Notices/2006/pt2006-6.htm. 
although it did propose adopting smaller market share loss tests for forbearance and winback. ${ }^{6}$ The Cabinet was apparently not satisfied, leading in September of 2006 to an order reversing the CRTC's VoIP decision. ${ }^{7}$ Going further, in December 2006 the Minister of Industry recommended to the Cabinet that it overrule the CRTC and order forbearance for residential service where there were three nonaffiliated facilities-based providers, two of which (including the ILEC) relied on fixed wires. ${ }^{8}$ Business service would be forborne with only the two fixedline providers. ${ }^{9}$ This proposal was adopted by the Governor in Council in April 2007. ${ }^{10}$

These developments raise a number of economic questions to explore, including the following issues:

Regulation within markets: Should an incumbent's substitute service for its regulated service necessarily also be regulated when there may be multiple and more prominent providers of the substitute?

Measuring potential share: An issue with share tests is determining the size of the likely market open to digital voice entrants. Should it be high volume customers who would get service at lower prices by switching to a VoIP provider?

Service market definition: To what extent is wireless in the market for wireline service? Would a weighting scheme be appropriate?

Geographic market definition: The CRTC and Competition Bureau ("Bureau") accepted that because consumers would not regard a telephone at some other location as a substitute for a telephone at their location, the relevant geographic market is the location. Other geographic market definitions were defended as mere aggregations of convenience. Is this sensible?

6. Reconsideration of Regulatory framework for voice communication services using Internet Protocol, Telecom Decision, CRTC 2006-53, paras. 78, 82-85 (Sept. 1, 2006) [hereinafter VoIP Reconsideration], available at http://www.crtc.gc.ca/archive/ENG/Decisions/ 2006/dt2006-53.htm.

7. Order of the Governor in Council Varying Telecom Decision CRTC 2005-28, P.C. 2006-1314 (Nov. 9, 2006) (Can.), as reprinted in 140 C. GAZ. 24 (Nov. 29, 2006) [hereinafter VoIP Variance], available at http://canadagazette.gc.ca/partII/2006/20061129/html/ sor288-e.html.

8. Hon. Maxime Bernier, Minister of Indus., Speaking Points: Variance of CRTC Decision on Local Forbearance, (Dec. 11, 2006) (Can.), available at http://www.ic.gc.ca $/ \mathrm{cmb} /$ welcomeic.nsf/503cec39324f7372852564820068b211/85256a5d006b9720852572410 07482f7! OpenDocument.

9. Id.

10. Order of the Governor in Council Varying Telecom Decision CRTC 2006-15, P.C. 2007-532 (Apr. 4, 2007) (Can.), as reprinted in 141 C. GAZ. 8 (Apr. 18, 2007) [hereinafter Local Variance], available at http://canadagazette.gc.ca/partII/2007/20070418/html/sor71e.html. 
Share tests and strategic responses: Might basing forbearance on market share introduce perverse effects on both incumbents and entrants?

Targeted low prices: Should an incumbent monopolist be allowed to offer discount services targeted at customers who it learns are switching to an entrant?

Defining "dominance": Some of the parties and the Bureau expressed at least potential concern with denial by ILECs to facilities that stand-alone retail service providers might need to remain viable. When does a single firm possess an "essential facility," and are effective competition law remedies available?

Building access: To what extent should ILECs be obliged to provide access to office buildings and apartments so entrants have an opportunity to compete for those customers?

Timing of intervention: Should monopolization in transitioning industries be controlled through ex ante regulation or ex post penalties?

Regulated conduct: Should competition law apply to forborne markets if competition to those markets depends on decisions made by the telecommunications regulator regarding access to still-regulated services?

This Article begins by describing these forbearance proceedings. Before, during, and after the CRTC proceedings, three other agencies played a leading role:

As in the U.S., industry participants supplied most of the comments with stakes in the outcome. We draw on those comments, in particular, the revealing perspectives taken by cable companies, the most likely entrant into the local telephone business.

A three-member Telecommunications Policy Review Panel('TPRP”) was appointed by the Canadian government in April 2005 to study Canadian telecommunications and make policy recommendations. ${ }^{11}$ It issued its report in March 2006, issuing numerous recommendations regarding forbearance and postderegulation competition enforcement, along with a range of other issues including universal service and information technology deployment. ${ }^{12}$

The Competition Bureau, the branch of the Canadian government charged with enforcing the Competition Act and serving as an advocate for competition more generally filed comments in the CRTC forbearance proceeding and to the TPRP. It made available for public comment a draft Bulletin on Abuse of Dominance in the Telecommunications Industry

11. Telecomm. Policy Review Panel, Final Report 2006 (2006) (Can.) [hereinafter TPRP Report], available at http://www.telecomreview.ca/epic/site/tprpgecrt.nsf/vwapj/ report_e.pdf/\$FILE/report_e.pdf.

12. Id. 
("Telecommunications Abuse Bulletin"), indicating how it might enforce the Telecommunications Act in this sector as it becomes more open to competition, and now it sees its role vis-à-vis the CRTC. ${ }^{13}$

Last, and perhaps most, the Minister of Industry, in charge of Industry Canada (which, along with Heritage Canada, oversees the CRTC) ${ }^{14}$ has the right to recommend that the CRTC reverse itself or that the Governor in Council overturn the CRTC's position.

After describing the roles of these parties in the development of Canadian telecommunications policy, we comment briefly on the economic questions listed above, followed by a brief conclusion that the Canadian experience has much to offer telecommunications policy analysts, particularly in the U.S.

\section{THE CRTC ForbeARANCE PROCEEDINGS}

\section{A. Local Telephone Service}

During the 1990s, the CRTC made a series of decisions to open a wide range of telecommunications services to competition and to lift price regulation of the services. The overall standard for forbearance or refraining from regulation is set out in Section 34(1) of the Canadian Telecommunications Act, ${ }^{15}$ where the Commission finds as a question of fact that to refrain would be consistent with the Canadian telecommunications policy objectives.

The objectives defined in Section (7) of that act include "( $f$ ) to foster increased reliance on market forces for the provision of telecommunications services and to ensure that regulation, where required, is efficient and effective." ${ }^{\prime 16}$

As was true of the U.S., by the mid-1990s, the primary remaining unregulated market was local telephone service, which in Canada is regulated nationally rather than provincially. In 1997, in anticipation of entry into local telecommunications, the CRTC set out a list of rules, not dissimilar to the framework in the U.S. Telecommunications Act and

13. Competition Bureau, Draft Information Bulletin on the Abuse of Dominance Provisions as Applied to the Telecommunications Industry (2006) (Can.) [hereinafter Telecomm. Abuse Bulletin], available at http://www.competitionbureau.gc.ca/PDFs/TAB_E.pdf.

14. Although the Canadian department through which the CRTC reports is the Ministry of Heritage, the Cabinet department with the greatest direct interest in telecommunications (as opposed to, say, content rules for broadcasting) is Industry Canada. It is as if the U.S. telecommunications decisions of the FCC were subject to review by the Secretary of Commerce and subject to being overruled by a vote of the Cabinet.

15. Telecommunications Act, 1993 S.C., ch. 38, § 34(1) (Can.), available at http://www.crtc.gc.ca/eng/LEGAL/TELECOM.HTM.

16. Id. at $\S 7(\mathrm{f})$. 
subsequent FCC proceedings, ${ }^{17}$ for regulating access to operation systems, "essential facilities," and interconnection with incumbent local telecommunications companies. ${ }^{18}$

In April 2004, Aliant Telecom, the ILEC for Atlantic Canada ${ }^{19}$ and a subsidiary of Bell Canada Enterprises, Canada's largest telecommunications carrier, petitioned the CRTC to forbear from requiring approved tariffs for local service in thirty-two of its exchanges. ${ }^{20}$ Aliant also requested that the CRTC remove winback rules, which prevented regulated local carriers from soliciting business from customers who had switched to a competitor for twelve months, and allow Aliant to waive service charges for those who switched back. ${ }^{21}$ According to Aliant, forbearance would, to combine clauses of the Telecommunications Act, be "consistent with the Canadian telecommunications policy objective. . . . to foster increased reliance on market forces." 22 Aliant's primary argument was that it was facing significant competition in those service areas from a facilities-based entrant, EastLink. ${ }^{23}$ Aliant stated that in these local exchanges, EastLink was serving twenty-one percent of the residential lines by the end of 2003 and thirty-three percent by August 2005, and it cited press reports of even more. ${ }^{24}$

Responding to this request on April 28, 2005, the CRTC issued a public notice requesting comment on the standards for forbearing from regulation of local service, including changing or amending the rules on winback and waiving switching charges. ${ }^{25}$ In the notice, the CRTC stated that forbearance would not be appropriate if the incumbent has "substantial market power."26 The CRTC would assess market power by looking at market share, willingness of consumers to switch to other providers in response to an increase in price, and the ability of those rivals to increase

17. See generally Telecommunications Act of 1996, Pub. L. No. 104-104, 110 Stat. 56 (codified as amended in scattered sections of 47 U.S.C.).

18. Local Competition, Telecom Decision, CRTC 97-8 (May 1, 1997), available at http://www.crtc.gc.ca/archive/ENG/Decisions/1997/DT97-8.HTM.

19. New Brunswick, Nova Scotia, Prince Edward Island, Labrador, and Newfoundland.

20. Forbearance from regulation of local exchange services, Telecom Public Notice, CRTC 2005-2, para. 5 (Apr. 28, 2005) [hereinafter Local Notice], available at http://www.crtc.gc.ca/archive/eng/Notices/2005/pt2005-2.htm.

21. Id. at para. 6.

22. Aliant Telecom., Inc., Forbearance Application for Residential Wireline LOCAL SERVICES IN SPECIFIED EXCHANGES, at para. 170 (Apr. 7, 2004) (Can.) (internal citations omitted), available at http://www.crtc.gc.ca/public/partvii/2004/8640/aliant/040407.zip.

23. Id. at paras. 33-59.

24. Id. at paras. 55-56; Letter from Richard A. Stephen, Director of Regulatory Matters, to Diane Rhéaume, Secretary General, CRTC (Sept. 26, 2006), available at http://www.crtc.gc.ca/public/partvii/2005/8640/aliant/050926.pdf.

25. Local Notice, supra note 20.

26. Id. at paras. 13-14. 
output in response to that demand. ${ }^{27}$ The relevant market would be determined using a framework roughly (but only roughly) akin to the U.S. Department of Justice and Federal Trade Commission Horizontal Merger Guidelines and the Bureau's Merger Enforcement Guidelines, in which one asks which products and over what region a firm "with market power" would need to control to "profitably impose a sustainable price increase" of unspecified magnitude or significance. ${ }^{28}$ The CRTC invited comment on a number of framework issues. These included designating the services to be forborne; defining markets along geographic and service dimensions; specifying criteria for forbearance; identifying which CRTC regulations might be retained; and handling transitional issues if, post-forbearance, market performance is not sufficiently competitive. ${ }^{29}$

After nearly a year of comments and replies, interrogatories and responses, and oral testimony, the CRTC issued its decision on April 6, $2006{ }^{30}$ To paraphrase, the CRTC set out three main criteria: (1) the ILEC has to demonstrate "rivalrous behaviour," e.g., active marketing, falling prices, and significant activity by competitors; ${ }^{31}$ (2) the ILEC has in place tariffs for "Competitor Services"-what might be called "network elements" in the U.S., including operational support systems-and meets specified quality standards in their provision; ${ }^{32}(3)$ most controversially, the ILEC needs to lose twenty-five percent of market share, calculated on the basis of wireline connections. ${ }^{33}$ The immediate controversies were whether this share was too high-the ILECs recommended much lower shares, e.g., five percent; their opponents recommended thirty to thirty-five percentand whether calculating shares based on wireline connections unduly excluded wireless phone service from the relevant service market. ${ }^{34}$

27. Id.

28. Id. at para. 17. The phrase "a firm with market power" introduces an unfortunate and unnecessary circularity: merger-based approaches invoke a "hypothetical monopolist." For the applicable merger guidelines from which this perspective is generally based, see U.S. DePT. OF Justice AND THE Fed. TRAdE COMM'N, Horizontal MERGer Guidelines (revised Apr. 8, 1997) [hereinafter HORIZONTAL MERGER GUIDELINES], available at http://www.usdoj.gov/atr/public/guidelines/hmg.htm; CAN. COMPETITION BUREAU, MERGER ENFORCEMENT GUIDELINES (2004) [hereinafter MERGER ENFORCEMENT GUIDELINES], available at http://www.competitionbureau.gc.ca/epic/site/cb-bc.nsf/vwapj/ 2004\%20MEGs.Final.pdf/\$file/2004\%20MEGs.Final.pdf.

29. Local Notice, supra note 20, at paras. 21-33.

30. Local Decision, supra note 1.

31. Id. at paras. 242(e), 279-80.

32. Id. at paras. 242(b)-(d), 256-78.

33. Id. at paras. 242(a), 244-54.

34. Id. at paras. 172, 195, 208, 229, 234 (Canadian Cable Television Association, EastLink, FCI/Yak, and Consumer Groups all supporting thirty percent). 
With respect to market definition, the CRTC found that the services market included primary and secondary lines, VoIP service, and bundles. ${ }^{35}$ It included resellers in the market with facilities-based providers but said that wireless was in a separate market on the basis of pricing, marketing, and a paucity of customers who had dropped wireline for wireless. ${ }^{36}$ It also placed business and residential services in separate markets, also on the basis of separate pricing and marketing. ${ }^{37}$

On the geographic side, the CRTC claimed that antitrust principles would warrant a finding that "the geographic component of the relevant market for local exchange services would be each location, as buyers would not be willing to substitute calling from their location for calling from another location." 38 However, it found that this level of aggregation, or the next lowest level, the local exchange, would be impractical. The CRTC considered proposals from the local exchange, through local connection or interconnection areas, up to an entire province or ILEC operating territory. It found that the appropriate geographic market on the basis of common interests and circumstances would be the census metropolitan area ("CMA"), with rural Canadian geographic markets identified as economic regions, as defined by Statistics Canada. ${ }^{39}$

The CRTC said that it would retain regulatory authority even if forbearance were granted in a number of areas. All carriers would be required to provide reciprocal interconnection, wireless interconnection, local number portability, 911 service, privacy safeguards, and a number of other consumer protections. ${ }^{40}$ ILECs would be required to offer stand-alone voice service under a ceiling price to protect legacy low-volume or lowincome subscribers who would not likely be served by competitors. ${ }^{41}$ ILECs would also provide directories and directory entries free of charge. ${ }^{42}$ The CRTC would also retain authority to rule on claims of undue discrimination in prices or terms of service. ${ }^{43}$ Perhaps most important, the competitor services requirements would force ILECs to provide facilities under tariff to firms that wanted to use those facilities to provide telecommunications services at retail. $^{44}$

35. Id. at paras. $45,47-48$.

36. Id. at paras. $45,57-62$.

37. Id. at paras 75-78.

38. Id. at para. 141.

39. Id. at paras. $141,158,165$.

40. Id. at app. C.

41. Id. at para. 452.

42. Id. at paras. 397-99.

43. Id. at para. 461 .

44. Id at paras. $262-275$. 
The CRTC retained the winback rule out of concern that ILEC immediate response would stifle entrants, but it allowed ILECs to go after lost customers after three months instead of twelve and would remove the rule for ILECs who had lost twenty percent market share..$^{45}$ Finally, with respect to the bottom line-Alaint's petition-the CRTC considered it only for the Halifax area, where Aliant had met the twenty-five percent share loss criterion. ${ }^{46}$ However, for Halifax, the CRTC found that Aliant had not provided competitor services meeting quality standards for a sufficiently long period and thus failed to meet the other forbearance tests. ${ }^{47}$

\section{B. VoIP Forbearance}

While its rulemaking on local forbearance was proceeding, the CRTC was also engaged in an assessment of whether to forbear from regulating ILEC-provided telephone service over digital Internet networks, i.e., VoIP. ${ }^{48}$ This proceeding was initiated by a request from Bell Canada in November 2003, with a public notice soliciting comment issued in April $2004 .^{49}$ In that notice, the CRTC set out a framework that it largely reiterated when it issued its decision in May 2005, just after issuing its request for comments on overall forbearance. ${ }^{50}$

The CRTC's reasoning can be essentially summarized by the following syllogism: ILECs (subject to the outcome of the general forbearance proceeding) were dominant in the market for standard voice telephone service, holding ninety-two percent of business revenues and ninety-eight percent of residential. ${ }^{51}$ VoIP and standard voice telephone service are in the same market. ${ }^{52}$ Therefore, the ILEC is dominant in VoIP and should remain regulated. ${ }^{53}$

This put the advocates of deregulation, primarily the ILECs, into a bit of a logical bind. To argue for forbearance from regulation of their VoIP services, they would have had to argue that VoIP and standard service were in separate markets to warrant separate treatment. On the other hand, that

45. Id. at paras. $483-86$.

46. Id. at para. 504.

47. Id. at paras. $505,508-10$.

48. Other telecommunications proceedings of particular note taking place during this time involved assessment of the implementation of price caps and the definition of essential facilities. We do not discuss these in detail here.

49. See Regulatory Framework for Voice Communication Services using Internet Protocol, Telecom Public Notice, CRTC 2004-2 (Apr. 7, 2004) at para. 6, available at http://www.crtc.gc.ca/archive/ENG/Notices/2004/pt2004-2.htm.

50. See VoIP Forbearance, supra note 3.

51. Id. at para. 131.

52. Id. at para. 126 .

53. Id. at paras. $170-71$. 
narrow market definition would exclude their main local service competitor, VoIP over cable networks, and thus undercut their main argument for forbearance overall.

However, the VoIP proceeding was not over-and, as we see below, neither was the proceeding regarding whether to continue regulation of local service overall. As we discuss in more detail below, under Canadian administrative law, the CRTC, although nominally an independent authority, is subject to review by the Cabinet Ministers, which in Canada is composed of members of Parliament from the ruling political party. In January 2006, it became a Conservative minority government. In May 2006, the Governor in Council issued an order to refer this VoIP decision back to the CRTC for reconsideration. ${ }^{54}$ This followed a recommendation of the then-Liberal Minister of Industry, David Emerson, in September of 2005 . $^{55}$ The primary basis for the reconsideration was the view that market forces should play an increasing role in Canadian telecommunications.

Following a call for comments, the CRTC issued a VoIP reconsideration decision on September $1,2006 .{ }^{56}$ The CRTC continued to refuse to forbear from regulating ILEC VoIP services, following its earlier reasoning. Its reasoning was reinforced by its decision a few months earlier not to forbear from regulating local exchange service unless conditions regarding market share, rivalry, and competitor services standards were met. ${ }^{57}$ It reiterated its view that VoIP and local exchange voice service were in the same market on the basis of purpose of the services, similar marketing, consumer perception of substitutability, and ability of VoIP and voice service to replace each other's functionality-particularly with local number portability. ${ }^{58}$

The CRTC argued, in addition, that forbearing VoIP but continuing to regulate circuit-switched service "would provide artificial incentives for the ILECs to invest in that technology, which could in turn distort the competitive market." 59 However, it did make a few concessions toward the Cabinet, which was clearly signaling its displeasure with the CRTC's pace of deregulation. In light of what it regarded as more recent data regarding

54. See VoIP Notice, supra note 5, at para. 6.

55. This doesn't necessarily reflect bipartisan consensus toward deregulation. Following the January 2006 Parliamentary election in which the Conservatives won the plurality of seats and took control of government from the Liberals, Mr. Emerson switched parties, and was given the portfolio of the Ministry of Foreign Affairs and International Trade.

56. See VoIP Reconsideration, supra note 6.

57. See id. at paras. $65,67,78$.

58. See id. at paras. 58-65.

59. Id. at para. 76. This followed the CRTC's discussion in its VoIP Forbearance decision of the ILEC incentive to migrate customers from regulated switched service to unregulated VoIP service. VoIP Forbearance, supra note 3, at paras. 158, 185. 
competition from non-ILEC VoIP, the CRTC solicited comments on whether the twenty-five percent lost-share-test for forbearance and the twenty percent lost-share-test for eliminating winback rules were appropriate. $^{60}$

This did not end the story, as the new Minister of Industry and Governor in Council intervened in the larger question of overall local exchange forbearance. The CRTC and the Governor in Council were not operating in a vacuum. Before describing those interventions and where forbearance stands today, we review actions of other significant participants in the Canadian policy debate-industry participants, the Telecommunications Policy Review Panel, and the Competition Bureau.

\section{THE PARTIES}

\section{A. Industry Participants}

A large number of private parties filed comments to the CRTC in the forbearance proceeding. The participants can be grouped into three categories-ILECs, facilities-based competitors, and firms offering VoIP over ILEC or cable facilities.

Although Aliant, the ILEC serving Atlantic Canada, petitioned for forbearance, the most extensive sets of comments were filed by the two largest ILECs in Canada, Bell Canada and Telus. Bell Canada is the primary ILEC serving Ontario and Quebec; Telus serves British Columbia and Alberta in western Canada. Needless to say, both parties supported deregulation, with filings substantially akin to those that ILECs might file in the U.S. on similar proceedings. Experts filing statements for Telus included Dennis Weisman of Kansas State University; Robert Crandall of the Brookings Institution, Alfred Kahn of Cornell University, and NERA Economic Consulting. ${ }^{61}$ Bell's experts included Donald McFetridge at Carleton University in Ottawa and Henry Ergas of Charles River's Australia office. ${ }^{62}$

Their arguments had much in common, citing the virtues of competition, pricing flexibility and the extent of competition. The relevant market for local services should include wireless providers and "access

60. See VoIP Reconsideration, supra note 6, at paras. 82-84.

61. Telus Communications Inc., Comments, Before the Canadian Radio-Television and Telecommunications Commission, Telecom Public Notice CRTC 2005-2, Forbearance from Regulation of Local Exchange Services (June 22, 2005), $\$ 9$.

62. Bell Canada and Télébec, société en commandite, Submission, Before the Canadian Radio-Television and Telecommunications Commission, Telecom Public Notice CRTC 2005-2, Forbearance from Regulation of Local Exchange Services (June 22, 2005), app. A, B. 
independent" stand-alone providers as well as facilities-based carriers. ${ }^{63}$ Bell's inclusion of stand-alone providers was predicated on continuation of wholesale regulation that would "ensure that ILEC competitors can readily buy essential and non-essential network elements to quickly expand their own facilities or resell ILEC services . . . ."64 For Telus, the key factor should be the presence of a single facilities-based alternative provider, generally cable-provided VoIP. ${ }^{65}$ Both parties thought that there should be a share test but recommended five percent (including stand-alone VoIP and wireless-only households), rather than the CRTC's twenty-five percent. ${ }^{66}$ Bell Canada argued that the relevant geographic market is the local exchange, while Telus thought that the relevant area for forbearance was the serving area of the ILEC. ${ }^{67}$

A second group is the stand-alone service provider, of which Primus Telecommunications Canada ("Primus") is a leading representative. Primus's main concern is that the CRTC preserve the ability of stand-alone providers to compete by ensuring access to ILEC facilities at regulated wholesale prices. $^{68}$ Primus characterizes stand-alone providers as equivalent to facilities-based providers, regarding vertical integration by cable into retail voice service by purchasing a stand-alone provider as preempting independent entry. ${ }^{69}$ In Primus's view, vertical integration will lead to an "inevitable price squeeze" that will put the stand-alone providers out of business. ${ }^{70}$ Even with wholesale access, stand-alone providers are at a competitive disadvantage by not being able to bundle wireless with telephone and Internet service. ${ }^{71}$ Primus argued that ILECs should be

63. Bell Canada and Télébec, société en commandite, Submission, Forbearance from Regulation of Local Exchange Services, Telecom Public Notice, CRTC 2005-2, at para. 63 (June 22, 2005) [hereinafter Bell Submission], available at http://www.crtc.gc.ca/public/ partvii/2005/8640/bell/050622_1.zip.

64. Id. at para. 146.

65. See Telus Communications, Inc., Comments, Forbearance from Regulation of Local Exchange Services, Telecom Public Notice CRTC 2005-2, at paras. 25-26 (June 22, 2005) [hereinafter Telus Comments], available at http://www.crtc.gc.ca/public/partvii/2005 /8640/telus/050622.zip.

66. See id. See also Bell Submission, supra note 63, at paras. 106, 114 (explaining that the five percent test was based in part on a test that the CRTC employs to determine when cable systems should be deregulated).

67. See Bell Submission, supra note 63, at paras. 100-04; Telus Comments, supra note 65 , at para. 140 (rejecting an analysis based on market definition as such and proposing instead to count the number of facilities based providers).

68. Letter from Jonathan L. Holmes, Director Regulatory Affairs, Primus, to CRTC, paras. 9, 13 (June 22, 2005), available at http://www.crtc.gc.ca/public/partvii/2005/8640 /primus/050622.doc.

69. Id. at para. 7 .

70. Id. at para. 8 .

71. Id. 
reregulated if their shares become sixty-five to seventy percent after forbearance, $;^{72}$ this presumably is a necessary condition for forbearance as well.

The most surprising and informative comments were those from a third group - the cable companies. Rogers is the primary cable competitor to Bell in eastern Canada, and Shaw is the primary competitor to Telus in western Canada. One would expect that if $\mathrm{X}$ is dominant, and $\mathrm{Y}$ is in its competitive fringe, $\mathrm{Y}$ would prefer that $\mathrm{X}$ be deregulated. $\mathrm{X}$ would raise its price, increasing $Y$ 's market share and profits. Here, however, the seemingly fringe competitors, the cable companies, wanted regulation retained.

The main institutional spokesperson for the cable sector is the Canadian Cable Television Association ("CCTA"). Rogers essentially signed onto the CCTA comments; ${ }^{73}$ Shaw filed extensive comments on its own. ${ }^{74}$ As with the ILECs, the comments resembled what one would see in the U.S.; CCTA submitted comments from David Gillen and Thomas Ross of the Sauder School of Business at the University of British Columbia. ${ }^{75}$ CCTA opposed forbearance, claiming that the local telephone market is not yet competitive. ${ }^{76}$ Before forbearance can be granted, the CRTC should require that ILECs have lost thirty percent to competitors and that, following annual reviews, competitive alternatives are "pervasive and sustained." 77

CCTA advocated as the geographic market the "local interconnection region," defined as an area over which local exchange carriers exchange traffic without going through an interexchange carrier. ${ }^{78}$ Within such an area, according to the CCTA, competitive carriers would not engage in price discrimination. ${ }^{79}$ This matters because the prime concern of the

72. Id. at para. 23 .

73. Written comments from Rogers Commc'ns, Inc. on Telecom Public Notice, CRTC 2005-2; Forbearance from Regulation of Local Exchange Services, para. 1 (June 22, 2005), available at http://www.crtc.gc.ca/public/partvii/2005/8640/rogers/050622.pdf.

74. Shaw Cablesystems G.P., Comments, Before the Canadian Radio-Television and Telecommunications Commission, Telecom Public Notice CRTC 2005-2, Forbearance from Regulation of Local Exchange Services (June 22, 2005).

75. Canadian Cable Telecommunications Association, Written Comments, Before the Canadian Radio-Television and Telecommunications Commission, Telecom Public Notice CRTC 2005-2, Forbearance from Regulation of Local Exchange Services (June 22, 2005), Attachment 1.

76. Written comments from the Can. Cable Telecomm. Ass'n on Telecom Public Notice CRTC 2005-2; Forbearance from Regulation of Local Exchange Services paras. 10-11 (June 22, 2005), available at http://www.crtc.gc.ca/public/partvii/2005/8640/ccta/050622.zip.

77. Id. at para. 12.

78. Id. at para. 40.

79. Id. 
CCTA is not that the ILEC would set prices too high but that it would engage in "targeted pricing," i.e., cutting price selectively to its competitor's customers. ${ }^{80}$ CCTA went on to argue that the ILECs had ninety-one to ninety-five percent of the residential customers across Canada, based on 2005 data, falling only about two percentage points per year. ${ }^{81}$ CCTA also argued that expansion by cable companies into the ILEC's markets would be time-consuming and with high sunk costs-and unlikely if the cable companies faced targeted pricing. ${ }^{82}$

Shaw's filing emphasized a different set of difficulties. It said that to enter the market, it would require access to Telus's "support structures" (e.g., poles), rights-of-way, multitenant buildings, and other "interconnection arrangements." ${ }^{, 33}$ Shaw claimed that Telus discriminated against it in getting such access. ${ }^{84}$ Shaw also proposed specific tests for reregulation: if competitors "experienc[e] substantial ... problems" getting access to support structures, or the ILEC obtains its preforbearance market share and it "sustains a price premium" of five percent. ${ }^{85}$

\section{B. Telecommunications Policy Review Panel}

While the CRTC undertook its forbearance review, the Canadian government initiated a separate review of telecommunications policy. At about the same time, David Emerson, the Minister of Industry in 2005, who led the Cabinet to have the CRTC reconsider its VoIP decision, appointed three leading telecommunications industry participants, specializing in technology, law, and finance, to a Telecommunications Policy Review Panel ("TPRP"). ${ }^{86}$ The TPRP spent roughly a year studying Canadian telecommunications, including an extensive process soliciting comments from largely the same participants in the CRTC proceedings, on many overlapping issues. On March 20, 2006, the TPRP issued a nearly 400-page report with 127 detailed recommendations, many with multiple parts. ${ }^{87}$ The report covered telecommunications policy objectives, choosing between

80. Id. at paras. $56-59$.

81. Id. at para. 79.

82. Id. at paras. 103-07.

83. Comments from Shaw Cablesystems G.P. on Telecom Public Notice CRTC 2005-2; Forbearance from Regulation of Local Exchange Service, paras. 9-10 (June 22, 2005), http://www.crtc.gc.ca/public/partvii/2005/8640/shaw/050622.zip.

84. Id.

85. Id. at para. 17.

86. Telecomm. Policy Review Panel, Who Are We?, (Can.) http://www.telecomreview.ca/epic/site/tprp-gecrt.nsf/en/h_rx00094e.html (last visited Mar. $15,2008)$.

87. TPRP Report, supra note 11. 
regulation and competition, access to support structures, spectrum policy, use of information technology, universal service, and institutional design.

The TPRP Report's ("Report") contents most germane to the CRTC's proceedings first are those in chapter three, "Economic Regulation." Most of the recommendations expressed a conviction that competition should be used instead of regulation "to the maximum extent feasible." The Canadian Telecommunications Act should be amended to put the presumption in favor of markets with regulation requiring a finding of market power, rather than presuming regulation absent a case for forbearance. ${ }^{89}$ Although this suggests that the burden of proof rests with those seeking regulation, the Report says in another recommendation that regulation be removed only after a review "concludes that there is no longer any significant market power . . ..,90

With regard to targeted pricing-the main concern raised by the opponents of forbearance-the Report recommended switching from ex ante prohibitions to ex post evaluation under the Competition Act. ${ }^{91}$ ILEC pricing should be fully flexible in forborne markets, "unless they are part of a practice that is determined to be anti-competitive conduct." $"$ The TPRP proposed that this ex post determination would be made by a "Telecommunications Competition Tribunal" ("TCT"). ${ }^{93}$ The TPRP recommended creating the TCT as a special agency that, during a five-year transition to deregulation, would determine if regulated markets sufficiently lack market power to be forborne; identify which wholesale access services (to stand-alone providers) should continue to be tariffed; review applications for reregulation and telecommunications mergers; and adjudicate allegations of allegedly anticompetitive conduct (e.g., targeted pricing).$^{94}$ The three TCT members would come from the CRTC, the head of the Competition Bureau or her designate, and a third member selected by the Governor in Council. ${ }^{95}$

Because of the change in governments in January 2006, the TPRP Report was delivered to a different Minister of Industry than the one who asked for it. Nevertheless, its deregulatory tone was in line with the view of the new Minister, Maxime Bernier. On June 13, Minister Bernier asked

88. Id. at Recommendation 3-1.

89. Id. at Recommendation 3-3.

90. Id. at Recommendation 3-4.

91. Id. at 3-23 to 3-25.

92. Id. at Recommendation 3-12.

93. Id. at 4-3 (using the Competition Tribunal, a quasi-judicial body that adjudicates noncriminal Competition Act cases in Canada, as the model for the Telecomm. Competition Tribunal).

94. Id. at 4-17; see also id. at Recommendations 4-15 to 4-17.

95. Id. at Recommendation 4-3 to 4-5. 
Parliament to issue a "policy direction" under the Telecommunications Act that the CRTC "rely on market forces to the maximum extent feasible," with regulation being efficient, proportionate, and neutral with regard to provider, technology, and entry. ${ }^{96}$ This set the stage for the Minister's subsequent actions on forbearance. But before we get to those, we turn to the Competition Bureau's participation.

\section{Competition Bureau}

The Competition Bureau, part of Industry Canada, is responsible for investigating and enforcing the Competition Act, which covers both traditional antitrust concerns such as collusion, abuse of dominance, mergers, and also consumer protection law. If it finds violations, it can (and in the case of criminal violations, must) hand over prosecution to the Competition Law Division of the Canadian Department of Justice. As with the U.S. competition agencies-the U.S. Department of Justice and Federal Trade Commission-it often acts as the advocate for competition principles in regulatory proceedings. ${ }^{97}$

In its role as competition advocate, the Bureau filed comments on June 22, 2005, before the CRTC regarding forbearance. ${ }^{98}$ The Bureau did not believe it had sufficient information to state whether the CRTC should forbear. ${ }^{99}$ It recommended that the CRTC use the Bureau's Merger Enforcement Guidelines as a framework for ascertaining whether an ILEC would have sufficient market power to merit continued regulation. ${ }^{100}$ Evidence on whether wireless was in the market was "inconclusive." "101 The Bureau deferred on specifics, instead detailing how it goes about defining markets. It did accept location-specific geographic markets as a starting point but then said that similarities across adjacent locations would warrant defining markets in terms of the extent of the overlap of the service footprints of rival networks. ${ }^{102}$ The Bureau recognized targeted pricing and

96. Hon. Maxime Bernier, Minister of Indus., Speaking Points: 2006 Canadian Telecom Summit, (June 13, 2006) (Can.), available at http://www.ic.gc.ca/cmb/welcomeic.nsf/503cec39324f7372852564820068b211/85256a5d00 6b97208525718c005d50ca! OpenDocument.

97. Under the Canadian parliamentary system, the Bureau also can play a similar advisory role in proposing and assessing legislative proposals that affect the level of competition in the Canadian economy.

98. Evidence from the Comm'r of the Competition Bureau on Telecom Public Notice CRTC 2005-2, Forbearance from Regulation of Local Exchange Services (June 22, 2005) (Can.), available at http://www.crtc.gc.ca/public/partvii/2005/8640/comm_comp/050 622.zip.

99. Id. at para. 10.

100. Id. at para. 29.

101. Id. at para. 122.

102. Id. at paras. 256-57. 
"consumer poaching" as a problem in theory but discussed it in terms of how it assesses general predatory pricing allegations. ${ }^{103}$ It suggested that such claims could be left to enforcement ex post if the conditions for forbearance were met. ${ }^{104}$

On August 15, 2005, the Bureau submitted comments to the TPRP on a largely similar set of issues. ${ }^{105}$ Perhaps its key contribution was that two facilities-based networks "may" provide sufficient competition to warrant forbearance if the entrant can match the ILEC's costs, consumers regard the offerings as having similar features and quality, and coordinated pricing is unlikely. ${ }^{106}$ The Bureau expressed some doubts about the prospect that targeted pricing could induce cable exit from voice telephony, particularly because most of its costs, the cable network itself, are sunk but again said that the Competition Act enforcement could handle situations that may arise. $^{107}$

The Bureau noted the difficulty of regulation in sectors with rapid technological change or participation by firms in an unregulated market (e.g., regulating wholesale access by an ILEC that also sells service at retail). ${ }^{108}$ In contrast to some industry participants, it said that competition among stand-alone providers does not render a market competitive if there is little competition at the facilities level. ${ }^{109}$ Moreover, competition at retail by facilities-based providers weakens the case for access regulation benefiting stand-alone providers. ${ }^{110}$ Interconnection regulation among facilities-based providers, however, may be needed to prevent mutual agreements that could raise service prices across the market. ${ }^{111}$

The Bureau reiterated its arguments made regarding the effectiveness of a duopoly in the Commissioner's oral testimony before the CRTC on September 27, 2005. ${ }^{112}$ It said there that the CRTC could streamline its

103. See id. at paras. $234-45,269-70$.

104. Id. at paras. 297-98.

105. Comments of the Commissioner of Competition, Telecomm. Policy Review (Aug. 15, 2005) [hereinafter Comments of the Commissioner], available at http://www.competitionbureau.gc.ca/PDFs/bureaucomments-tpr-2005.08.15.pdf.

106. Id. at para. 29.

107. Id. at paras. 33-34.

108. Id. at paras. 45-47. See also Timothy J. Brennan, Why Regulated Firms Should be Kept Out of Unregulated Markets: Understanding the Divestiture in U.S. v. AT\&T, ANTITRUST BULLETIN 32, $741-93$ (1987) (discussing the competitive risks in allowing regulated firms to participate in unregulated markets).

109. Comments of the Commissioner, supra note 105, at para. 60 .

110. Id. at paras. $56-58$.

111. Id. at paras. 71-72. See also Timothy J. Brennan, Industry Parallel Interconnection Agreements, Information ECONOMics AND Policy 9, 133-49 (1997).

112. Forbearance from Regulation of Local Exchange Services, Oral Presentation of the Commissioner of Competition, Telecom Public Notice CRTC 2005-2 (Sept. 27, 2005) (Can.), available at http://www.competitionbureau.gc.ca/PDFs/2005-09-27_comm_ 
assessments by granting forbearance when there are two facilities-based providers, including the ILEC. The ILEC's rival has to be able to offer a product in the relevant market with variable costs no greater than the ILEC's, lack capacity constraints, and have shown it can retain customers. ${ }^{113}$ Evidence of rivalry and the unlikelihood of collusion would also be required. ${ }^{114}$ Predation was again thought unlikely, but as it cannot be ruled out completely, a temporary price ceiling with downward pricing flexibility could be justified as a transitional measure. One notable omission here was any mention of a share-based test.

The Bureau's most recent statement followed the CRTC's decisions on forbearance and the TPRP Report, in a draft Bulletin on Abuse of Dominance in the Telecommunications Industry, and provides public guidance on how it would apply abuse of dominance provisions in Canada's Competition Act to the telecommunications industry if and when local service is forborne from regulation. ${ }^{115}$ The purpose was to describe Bureau enforcement policy as deregulation ensues and the telecommunication sector falls less under the authority of the CRTC and more under general competition law. ${ }^{116}$ Since the main concerns raised regarding forbearance would fall primarily under the abuse of dominance provisions in the Competition Act-either refusal to grant access to standalone service providers or targeted predatory pricing-confidence in forbearance could depend on confidence that ex post enforcement rather than $e x$ ante regulation would suffice to prevent anticompetitive conduct. ${ }^{117}$

speech.pdf.

113. Id. at para. 11.

114. Id. at paras. $37-41$.

115. Telecomm. Abuse Bulletin, supra note 13. The June release date is given in Press Release, Competition Bureau, Commissioner of Competition Comments on Government's Decision to Deregulate Local Telecommunications Sector (Apr. 4, 2007) (Can.), available at http://www.competitionbureau.gc.ca/internet/index.cfm?itemID=2296\&lg=e. Such Bureau statements are not infrequent. Its bulletins and guidelines cover a wide range of practices including general abuse of dominance, mergers and predatory pricing, along with issuances regarding specific industries or sectors including intellectual property, gasoline, and groceries.

116. The document could also be a response to the TPRP's recommendation to create a Telecommunications Competition Tribunal. See TPRP Report, supra note 11 and accompanying text. Since the Bureau would both prepare cases and, under that proposal, adjudicate them, there could be some interest in describing how general competition law would apply and, implicitly, to suggest that a TCT is unnecessary.

117. In Canada, like the U.S., the stated objective of competition law is protecting the welfare benefits of competition rather than the status of particular competitors. Unlike the U.S., Canada uses a total welfare (weighted for distributional effect when appropriate) rather than consumer welfare. Merger enforcement has brought this out most clearly. In its abuse of dominance provisions, efficiency considerations on the supply side may play a role in establishing motives for allegedly exclusionary conduct other than targeting rivals. 
Fourteen comments on the draft were posted on the Bureau's Web site as of January $29,2007 .^{118}$

The draft Bulletin begins by discussing market definition, which is problematic for single firms whose profit-maximizing price is at levels where consumers begin to regard other products as substitutes. ${ }^{119}$ Acknowledging the difficulty, the Bureau lists a number of empirical tests regarding lack of price correlation and substitution to indicate whether a single firm, e.g., a forborne ILEC, meets statutory criteria for dominance. ${ }^{120}$ On the geographic side, the Bureau accepts the view that the customer's location is the theoretically proper geographic market but admits the value of aggregation on the basis of the similarity of competitive alternatives. ${ }^{121}$

After discussing the roles of market share, entry barriers, and large buyer bargaining in assessing the magnitude of market power, the Bureau turns to potential abusive practices. The Bureau calls its first category "raising rivals' costs and market foreclosure." 122 Under this category falls denial of interconnection or access to network elements. ${ }^{123}$ The Bureau will consider them only when the access is denied to unregulated services, citing a "regulated conduct" defense-that regulatory authority takes precedence-when access remains overseen by the CRTC. ${ }^{124}$ The Bureau also discusses in this section margin squeezes and denials to "essential facilities." 125 Although denial of access may meet the definition of an anticompetitive act if it eliminates stand-alone providers whose customers lack access to competitive alternatives, the Bureau will inquire if there would be substantially more competition in downstream retail markets but for the practice. ${ }^{126}$ Mere elimination of stand-alone providers is not

118. Competition Bureau Seeks Public Comments on its Bulletin on the Abuse of Dominance Provisions as applied to the Telecommunications Industry (Jan. 29, 2007) (Can.), available at $\mathrm{http}: / / \mathrm{www} . c 0 m p e t i t i o n b u r e a u . g c . c a / i n t e r n e t / i n d e x . c f m ? i t e m I D=2251 \& \mathrm{lg}=\mathrm{e}$.

119. Misdefining firms with market power as competitive because of rivalry at monopoly prices is known as the Cellophane fallacy, following an error by the U.S. Supreme Court in a 1956 decision in an antitrust case brought against DuPont. United States v. du Pont \& Co., 351 U.S. 377 (1956).

120. Telecomm. Abuse Bulletin, supra note 13, at 5-6.

121. Id. at 9.

122. Id. at 14 .

123. Id. at 15 .

124. Id.

125. Id. at 16-19. The Bureau elaborated its views on what makes a facility essential in Review of Regulatory Framework for Wholesale Service and Definition of Essential Service, Evidence of the Commissioner of Competition, Telecom

Public Notice, CRTC 2006-14 (Mar. 15, 2007) (Can.), available at http://www.crtc.gc.ca /public/partvii/2006/8663/c12_200614439/737543.zip.

126. Telecomm. Abuse Bulletin, supra note 13, at 18, 22. This "but for" test was set out by the Canadian Court of Appeal in Commissioner of Competition v. Canada Pipe Co., 2006 FCA 233, para. 38 (Can.). 
sufficient to conclude that a squeeze or access denial would violate the Competition Act. ${ }^{127}$

The other categories of conduct include predatory pricing, targeted pricing, and bundling. ${ }^{128}$ With regard to predation, the Bureau will consider cases only when alleged predatory prices are below both the complainant's and alleged predator's costs and recoupment of losses from below-cost pricing is likely. ${ }^{129}$ In doing so, the Bureau recognizes that residual regulation could inhibit recoupment (by capping postpredatory prices) or encourage it (if regulators allow cross-subsidization that allows costs to be passed on to the ratepayers). ${ }^{130}$ For targeted pricing, the Bureau would require similar tests or "ancillary evidence" of competitive harm, noting the difficulty it and the Competition Tribunal have expressed in distinguishing procompetitive from anticompetitive price cuts. ${ }^{131}$ Bundling could be illegal both as a method for raising rivals' costs, akin to tying, or as a form of predation. $^{132}$

\section{THE GOVERNOR IN COUNCIL CUTS TO THE CHASE}

As noted above, the Cabinet of Ministers can overturn a CRTC decision. On December 11, 2006, Industry Minister Bernier proposed to do so regarding forbearance. ${ }^{133} \mathrm{He}$ found that the CRTC's forbearance criteria were too strict and would prevent the telecommunications sector from realizing the full benefits of market forces. ${ }^{134} \mathrm{He}$ proposed replacing the CRTC's share tests with a simple one-ILECs would have full pricing flexibility in regions where subscribers have access to a telephone company, cable broadband provider, and wireless service unaffiliated with the first two. ${ }^{135} \mathrm{He}$ also proposed lifting all winback rules. ${ }^{136}$ The accompanying Regulatory Impact Statement noted that an acceptable alternative would be the Bureau's proposed test, which would require only two competitors-cable and ILEC - with a demonstration that the cable company offers a viable alternative at variable costs no greater than the

127. Telecomm. Abuse Bulletin, supra note 13, at 16.

128. Id. at 19-22.

129. Id.

130. Id. at 21-22.

131. Id. at 22.

132. Id. at 22.

133. Bernier, supra note 8.

134. Id.

135. Id.

136. Id. 
ILEC's and lacks significant capacity constraints, with evidence of "vigorous rivalry."137

After the requisite 120-day period for consultation and public comment, the proposed variance was adopted by the Governor in Council on April 3, 2007. ${ }^{138}$ In its Order, the Governor in Council replaced the CRTC's geographic market analysis and determinations with a single statement that the local exchange is "the appropriate geographic component of the relevant market." 139 Applications for forbearance will be based on exchanges, although applications "for a number of contiguous local exchanges" may be considered as a single application. ${ }^{140}$ The order also repealed all winback prohibitions. ${ }^{141}$

Most significantly, the CRTC's aforementioned forbearance criteria and the supporting discussion would forbear if either the ILEC "lacks market power"- the phrase the Order uses to describe settings in which a second provider meets the Bureau's criteria stated above-or for residential customers, two independent facilities-based providers, at least one of which is wire-based, "capable of serving at least $75 \%$ of the number of residential local exchange service lines that the ILEC is capable of serving," and for business customers, one fixed line meeting the seventy-five percent capability test. ${ }^{142}$ The ILEC would also have to meet the quality standards for competitive services "during a six month period, beginning no earlier than eight months before its application for local forbearance and ending at any time before the [CRTC's] decision respecting the application." 143

The phrasing of the final Order raises a number of questions for Canadian regulatory and competition policy. In the direction of being too strict, the requirement that competitors be capable of serving at least seventy-five percent could mean that seventy-five percent of the people might find them as an alternative. However, it could also mean they should be able to handle demand from seventy-five percent of the customers at once. If so, substantial excess capacity is necessary for competition. Seventy-five percent of car drivers could choose Hondas, but Honda probably isn't capable of selling cars to seventy-five percent of all drivers.

On the other hand, the order might be too lax. An ILEC could meet the quality criterion for deregulation if it met competitor service standards

137. Order Varying Telecom Decision CRTC 2006-15, Regulatory Impact Analysis, Dec. 7, 2006, as reprinted in 140 C. GAZ. 50 (Dec. 16, 2006), available at http://canadagaz ette.gc.ca/partI/2006/20061216/html/regle6-e.html.

138. Local Variance, supra note 10.

139. Id. at para. 141 .

140. Id. at para. 515 .

141. Id. at para. 483.

142. Id. at para. 2(a)(ii).

143. Id. at para $242(\mathrm{~b})$. 
for six months but then stopped interconnecting or providing access to monopoly conduits and rights of way for two months prior to the forbearance decision. More broadly, interpreting what we might label as the Bureau's "one comparable cost, non-cooperating rival" standard as saying that a firm lacks market power may make it difficult if not impossible for the Bureau to contest mergers unless the merger creates either an outright monopoly or facilitates a monopoly cartel.

\section{ECONOMIC COMMENTS AND CRITIQUES}

These developments invite comment on a number of economic matters, to which we turn. Many of these warrant and have received extensive analysis elsewhere. ${ }^{144}$

\section{A. Regulation Within Markets}

As discussed above, prior to the Order in Council, the CRTC planned to continue to regulate the ILEC provision of VoIP over digital broadband DSL. That decision was not predicated on the competitive superiority of the ILEC's VoIP or dominance in VoIP as such. Rather, it was because the ILEC's VoIP service was seen as a substitute for its standard circuitswitched service, which was regulated. This seems paradoxical. If there are substitutes for VoIP, and VoIP is in the same market as circuit-switched service, then one might conclude that the ILEC lacks market power in the latter and thus should be forborne.

However, assume that VoIP is a substitute, but other providers are limited in some way, either by capacity constraint or because a substantial fraction of subscribers would not switch. Then, a regulator might have a legitimate question whether to deregulate VoIP. The criterion would be whether deregulation of a substitute would lead the regulated firm to respond by migrating customers to that alternative. If this is possible, deregulating the alternative could reduce welfare by evading the price control and giving consumers an alternative that many deem inferior. Of course, if this is not possible - consistent with the capacity constraint argument supporting continued regulation in the first place - the ability of the ILEC to respond tactically to partial forbearance would be limited and the case against it weakened.

\section{B. Measuring Potential Share}

Under virtually any set of credibly proposed conditions for forbearance, the competitive salience of VoIP is crucial. As we see below, 
looking at actual shares may be problematic because of strategic reactions induced among some and perhaps all competitors. Nevertheless, the assessment of ILEC market power depends on the extent to which telephone customers would be willing to switch to VoIP if the price of ILEC service were to increase by some undesirable amount, e.g., the small but significant non-transitory increase in price used to define markets in the Canadian and U.S. merger guidelines. ${ }^{145}$

In assessing the potential for VoIP competition, one proposal would be to count the high-volume customers who have not yet switched to a VoIP provider but would save money by doing so, as the reduced usage charges would make up for recurring fixed fees. On the other hand, customers who would have lower rates under VoIP than with the ILEC but have not switched have revealed a preference for the ILEC's service. This may be based on consumer "inertia," in particular, the costs of assessing the merits of alternatives, service characteristics (e.g., the independently powered ILEC network's reduced vulnerability to electricity outages), or perceived reliability of the provider. Regardless of the basis for the preference, the size of the subscriber base that would nominally have lower rates under VoIP but has not switched could speak to the weakness of VoIP as a competitor, not to its strength.

\section{Service Market Definition}

As just discussed, other than ILEC arguments supporting VoIP forbearance prior to general forbearance of local exchange service, opinion was virtually unanimous that VoIP was in the same service market. As we see below, wireless service has been more controversial. The Order of Council varying the CRTC decision adopted a middle ground, saying that an independent wireless provider would warrant forbearance but only if a wireline provider is also in the market. ${ }^{146}$ Two wireless providers would not be enough, implying that wireless is something of a partial competitorrelevant, but insufficient.

Such an approach has analogues in the U.S. The New York State Department of Public Service has proposed a quantitative variant on this theme, an index of market competition as follows:

The index gave weights to various options based on a judgment of the degree of substitutability of the service and economic readiness of the competitive carriers to expand existing offerings. The Department assigned the following weights: cable telephone (weight of 1), CLEC (a weight of 1 where providing residential service and a weight of 0.5

145. See Horizontal MERGER GuIDELINES, supra note 28, at $\S 1.0$; MERGER ENFORCEMENT GUIDELINES, supra note 28 , at n. 20 .

146. Local Variance, supra note 10; replacement paragraph 242(a)(ii) to Telecom Decision CRTC 2006-15, supra note 1. 
where providing only business service), wireless (weight of 0.5 ), [DSL-enabled] VoIP telephone (weight of 0.75 ). Beyond the traditional wireline carrier, if competition were available from all the sources described above in a given wire center, an index value of 3.25 would be determined for that wire center. In the Department's judgment, an index value of 2.75 or above indicated a level of competition sufficient to conclude that competitive carriers will not be impaired without access to unbundled switching. In other words, the wholesale market was sufficiently open to competition to relax wholesale regulation. ${ }^{147}$

According to this index, in New York, cable VoIP is in the market; wireless gets a value of .5. On this account, two wireless providers would have the same competitive significance as one cable provider (or other CLEC). Apparently, stand-alone VoIP providers using ILEC facilities would provide more competition than wireless. On the New York scale, the Governor in Council would forbear with an index of 1.5, less than the 3.25 New York recommended in 2005 . All this said, the only comment here is that to my knowledge there is no analogue for counting firms as partial participants in a market for competition assessments, e.g., in calculating concentration measures or ascertaining competitive effects in merger cases. The theoretical underpinnings, if any, of such measures remain to be developed. ${ }^{148}$

\section{Geographic Market Definition}

Both the CRTC and the Bureau took the view that the appropriate geographic market definition for local exchange services is the consumer's location (e.g., house). The basis for this claim is that consumers would not regard a phone at some other location (e.g., the next door neighbor's house) as a substitute. The only reason to use larger areas, such as the local exchange (as the Governor in Council used) or the metropolitan area (as proposed by the CRTC) was to aggregate the actual markets into something administratively convenient.

Customer reluctance to go next door to use the phone misses the point by proving too much and not enough. It proves too much because this behavior could be applied to virtually any consumer product, not just telephone service, implying that the customer's location is almost always the geographic market in antitrust analysis. Since most consumers would

147. New York Public Service Communication, Hearing before Commission to Examine Issues Related to the Transition to Intermodal Competition in the Provision of Telecommunications Services, Order Initiating Proceeding and Inviting Comments, Case 05-C-0616 (June 29, 2005), at 9.

148. A second issue regarding service market definition is the extent to which static data on people who have switched from ILEC service to wireless (or VoIP, for that matter) provides useful information on market definition. Brennan, supra note 139 . We discuss this below in considering the merits of share-based tests for forbearance. 
not regard borrowing a neighbor's car as a substitute for using their own car, the relevant market for cars would have to be the individual driveway or parking space. One's unwillingness to cart dirty laundry next door would make the geographic market for washers and dryers the laundry room. Customer location proves not to be specific enough, however, because, on that account, the geographic market is unstable for products consumed while the customer is moving. That $\mathrm{X}$ would not want to borrow $\mathrm{Y}$ 's cell phone to make calls would mean that the relevant geographic market for cell phones and cell phone service is wherever the customers happen to be at any moment. The same might be said of cars, iPods, and shoes, with geographic markets apparently in constant flux.

The error in the CRTC and Bureau's reasoning that leads to this absurd geographic market definition is two-fold. First, it conflates the characteristics of a product and service with the geographic nexus of competition. Being able to make calls from one's home, or from one's pocket with a cell phone, is a characteristic of the service being offered. It places conventional telephone service in a separate market from, say, the service offered by pay phones. As claimed by the CRTC and partially claimed by the Governor in Council (and New York State), wireless telephones may not be in the same market as wireline phones, but for similar reasons-only one allows mobility but (so far) at higher prices. Taxi service may not be a substitute for owning one's own car, outside crowded urban areas. But in all those cases, the issue is the characteristic of the product or service being purchased by consumers, not where the consumer happens to be.

The second related error is that the purpose of identifying geographic markets is to identify the locations of sellers that consumers regard as substitutes, not the location of the services or products those sellers provide. For local exchange service, the telephone companies serving Montreal are not in the same geographic market as those serving Toronto, because someone living in Toronto would not regard services offered by Montreal companies as substitutes. This is so obvious that geographic market definition in local exchange service is an uninteresting exercise.

This obviousness may be what led the CRTC and Bureau to adopt a facially incorrect geographic market definition, thus making geographic markets to be significant. But the Governor in Council probably came closest to getting it right by using the phrase "the appropriate geographic component of the relevant market." 149 The most important location question is not the geographic location of the sellers, but the extent to which consumers in some area-the local exchange, interconnection area, 
metropolitan area, or province-have access to multiple providers. That, rather than the location of sellers (the usual application in merger cases) or the locational characteristics of the service (the error here), matters for asking whether the benefits of forbearance in the area in question to those who have multiple alternatives within the exchange exceeds the costs of forbearance from the potential exercise of market power to those who do not. ${ }^{150}$

\section{E. Share Tests and Strategic Responses}

Prior to the Governor in Council's variance of the CRTC decision, virtually all participants in the proceeding accepted that lost market share would be a criterion for forbearance. ${ }^{151}$ Those in favor of forbearance, such as the ILECs, were willing to go as low as five percent, while opponents of forbearance asked for a minimum of thirty percent. ${ }^{152}$ The CRTC chose twenty-five percent for forbearance from regulation and twenty percent for elimination of the winback restrictions. ${ }^{153}$ The leading exceptions were the Bureau and, later, the Governor in Council. ${ }^{154}$ The Bureau's criteria spoke to whether the ILEC's rival or rivals offered substitute services with similar costs, lacked capacity constraints, and would compete rather than collude. ${ }^{\text {Iss }}$ The Governor in Council adopted the Bureau's criteria as one basis for forbearance and also would forbear simply by counting alternatives (with at least one wireline) that could offer service to seventyfive percent of the lines in a local exchange. ${ }^{156}$

While share tests appeal to an intuition that customer shifting speaks to the competitive power of rivals, it is a highly problematic test and should be avoided for two reasons. The first is that whether any firm has market power at current prices depends not on the number of people who have switched at those prices, but whether enough would switch at higher prices to make such increases unprofitable. For deregulation, "current" prices would be regulated prices; and the higher prices might be those after forbearance. ${ }^{157}$ The number who have switched indicates a shift in the

150. The ability of ILECs to price discriminate between those who face competition and those who do not may be strategically significant, as discussed below in considering policies toward targeted pricing.

151. See text accompanying infra notes 61-85.

152. See text accompanying infra notes $66,72,77$.

153. See text accompanying infra notes $1-2$.

154. See text accompanying infra notes 114-15, 134-35

155. See text accompanying infra notes 112-14.

156. See text accompanying infra notes 135-37.

157. Brennan, supra note 144. 
demand curve but not necessarily an increase in its elasticity, which is what determines market power. ${ }^{158}$

A second problem with share tests is the foreseeable strategic responses of the sector's participants. In this context, the concern is twofold. Those seeking forbearance would want to undertake tactics to boost the market share of their competitors. The usual way to do so is by setting prices higher, but if regulation prevents that, the ILECs might instead reduce service quality. Either tactic obtains deregulation by making consumers worse off. On top of that, here, the rivals, particularly cable VoIP providers, want to retain regulation to prevent the ILECs from charging low prices. If so, the cable companies too would want to hold down their market shares to prevent forbearance. Hence, a share test has the perverse result of inducing the two major local exchange service rivals to try to reduce their market shares, "competing" to offer worse service at higher prices.

\section{F. Targeted Low Prices}

For ILEC rivals to benefit from continued regulation, that regulation must inhibit ILEC price cutting. An obvious criticism of this position is that rivals always want to keep up the market price, to the detriment of consumers. For the rivals' argument to protect competition rather than competitors, ILEC price cutting must injure consumers in the long run.

The textbook example of this behavior is predatory pricing. ${ }^{159}$ The "Chicago school" of antitrust called concern with predation into question. Efforts to cut prices now would pay off only if the alleged monopolists could raise prices after firms exit. Such price increases would be profitable only if firms were dissuaded from re-entering, which postpredation high prices would encourage. ${ }^{160}$ More recent theories established the possibility that low prices could be credible, but only if the predator had a reputation for irrational price-cutting to preserve or if low prices signaled low capital or production costs. ${ }^{161}$ Because these circumstances are unlikely and pricecutting is something that competition encourages, firms should be immune from prosecution unless prices go so low as to be inconsistent with

158. An example may be useful. Because of cars, fewer people ride horses to work. But that does not place horses and cars in the same market for antitrust purposes. Doing so would imply that one would permit a merger of all car companies because consumers would switch to horses if the price of cars rose by more than a trivial amount.

159. ERnest Gelhorn \& William Kovacic, ANTITRUST Law and ECONOMICS, $137-44$ (1994).

160. See Frank H. Easterbrook, Predatory Strategies and Counterstrategies, 48 U. CHI. L. REV. 263 (1981).

161. Patrick Bolton et al., Predatory Pricing: Strategic Theory and Legal Policy, 88 GEO. L. J. 2239, 2260-65 (2000). 
competition under any plausible circumstance. This is the primary argument for why only below-cost prices should be predatory, even though above-cost strategic price cuts may reduce welfare. ${ }^{162}$

Targeted pricing may be more credible in that the incumbent monopolist need not sacrifice profits across the entire market; it need only sacrifice those to customers who might switch to the entrant. If the predator can restrict price cuts to an identified subset of consumers that find the entrant relatively attractive, the prospect of price cuts, even if above the incumbent's costs, could deter entrants with entry costs high enough to now be unprofitable but not so high to have kept them out in the first place. ${ }^{163}$ As the Bureau's draft Telecommunications Abuse Bulletin acknowledges, one is still left with the problem of distinguishing good price cutting from bad price cutting. ${ }^{164}$ In practice, as the Bureau says, the plaintiff should bear a high burden of proof, showing that targeted prices meet general predatory tests or providing substantial evidence (e.g., internal planning documents) that a targeted price strategy would be effective and provide a sufficient credible future threat to lead to higher prices overall.

\section{G. Defining "Dominance"}

For purposes of ascertaining whether a practice by a forborne ILEC or other telecommunications firm constitutes "abuse of dominance" in

162. For the former, see Einer Elhauge, Why Above-Cost Price Cuts to Drive Out Entrants Are Not Predatory-and the Implications for Defining Costs and Market Power, 112 YALE L.J. 681 (2003); for the latter, to which Elhauge is responding, see Aaron Edlin, Stopping Above-Cost Predatory Pricing, 111 Yale L.J. 941 (2002).

163. Mark Armstrong, Recent Developments in the Economics of Price Discrimination, in ADVANCES IN ECONOMICS AND ECONOMETRICS: THEORY AND APPLICATIONS, NINTH WORLD CONGRESS 97, 127-28 (Richard Blundell et al, eds. 2006).

164. Telecomm. Abuse Bulletin, supra note 13, at 21-22. Filings by economists on behalf of Bell Canada in the CRTC's proceeding on price cap (McFetridge, Hariton and Krause) suggested that allowing for price discrimination can increase the intensity of price competition. Bell Aliant Regional Communications, Limited Partnership, Bell Canada and Saskatchewan Telecommunications, Submission, Canada Radio and Telecommunications Commission, Telecom Public Notice CRTC 2006-5. The intuition is that if each firm has a set of customers who prefer its product, allowing it to cut prices selectively will increase the willingness of each firm to try to capture the other's customers. As each becomes more interested in trying to capture the other's prime customers, the increased competitive intensity reduces price to all customers. See also James Cooper et al., Does Price Discrimination Intensify Competition? Implications for Antitrust, 72 ANTITRUST L. J. 327, 373 (2005).

This theory requires that consumers have negatively correlated preferences across sellers, i.e., those willing to pay more for VoIP service have a lower willingness to pay for ILEC voice service, and vice versa. For the theory to be empirically important, each firm must be able to set prices substantially above cost to its preferred customers, suggesting that they (particularly the ILEC) might have sufficient market power to fail to meet conditions for forbearance. 
Canadian law, or whether it should or should not be regulated, one needs to determine when a firm is dominant. A special case is when a firm has an "essential facility." Leaving aside legal questions of whether an "essential facility" doctrine has any force in antitrust law, ${ }^{165}$ the definition question regarding whether a single firm has market power remains. This economic question, as the Bureau's Telecommunications Abuse Bulletin points out, is difficult. ${ }^{166}$ It differs from defining markets in merger cases, because there the issue is whether combining firms would make matters worse, not whether matters are bad at present. ${ }^{167}$ With single firm conduct, the hypothetical "but for market power" price is not observed.

The definition of market power suggests an answer in principle. Market power implies that a firm finds it profitable to reduce output in order to raise price. If the firm were not able to raise price, because of an exogenously-enforced ceiling below the price it is charging, it would not find output reductions profitable. A mandated price reduction would lead to an increase in output. This differs from competition, in which a reduction in price reduces a firm's output. With competition, the firm's only interest is in selling as much as it can at the going rate, and reducing price makes sales at the margin unprofitable, reducing supply.

We then have a test: reduce price by a small but significant, nontransitory amount, and see what the firm does. If reducing price increases output, the firm has market power; if not, it doesn't. ${ }^{168}$ Unfortunately, natural experiments supplying an exogenous price limit are unlikely. The test requires regulation to see what the firm does; a firm, realizing the purpose of the test, would cut output just to ensure that regulation is not imposed. We are thus probably left with having to judge dominance, or whether a "facility" is "essential," based on conventional indicia of competitiveness, with the Cellophane fallacy kept in mind. ${ }^{169}$

\section{H. Building Access}

The Shaw comments in the CRTC's local forbearance proceeding illustrated the importance that many parties attach to the ability to have access to multiple dwelling units ("MDUs"), primarily office buildings and apartments that provide the premises for numerous potential customers of local telecommunications services. The intuition behind this concern is

165. Verizon v. Trinko, 540 U.S. 398 (2004) (reiterating that the essential facility doctrine has no legal force in U.S. antitrust law).

166. Telecomm. Abuse Bulletin, supra note 13, at 5-6.

167. Lawrence White, Market Definition in Monopolization Cases: A Paradigm is Miss ing, in IsSUES IN COMPETITION LAW AND POLICY (Wayne D. Collins ed., 2007).

168. For more on this test, see Brennan, supra note 149.

169. See supra note 119. 
compelling. Tenants in an MDU have no opportunity to switch suppliers unless those suppliers can get lines to them. Wireless providers are not as handicapped, but cable providers, relying on physical wires to carry voice, video, and broadband data, would be impeded without access.

This intuition is not as compelling as it may appear. One could view the telecommunications service supplied by an MDU provider as one of many amenities that are part of the package offered to potential tenants in the overall market for apartments or offices, whether leased or purchased. In principle, it would be equivalent to say that MDU owners should provide ventilation ducts to alternative heating and air conditioning providers so that they could compete against the provider already in the building. Running additional lines into an already-constructed building is, if not as bad as running new ventilation systems, a nontrivial installation project.

However, we are not starting from an equal starting point. The ILEC begins with one hundred percent of the market, as the entity that installed the wiring to and into the MDU. With deregulation, the ILEC would in effect have exclusive access to those buildings. It would thus have market power, not over telecommunications per se, but over the buildings themselves, as the only option for tenants would be to not rent offices or to go to new construction. ${ }^{170}$ If new construction would constrain market power of existing buildings, there is no problem, as those tenants who preferred an alternative telecommunications provider could find one in a new building, just as apartment renters can choose buildings on the basis of the type of exercise equipment. If not-if we would care if all the existing buildings merged - then a remedy would be necessary to prevent a forborne ILEC from exercising market power. In theory, the best remedy would be for the ILEC to sell the MDU-specific access lines to the MDU at the depreciated book value, to ensure that the ILEC is properly compensated relative to the expectations of cost recovery that it had when it constructed those lines.

\section{Timing of Intervention}

Whether to forbear represents a choice between ex ante regulation of prices and business practices and ex post law enforcement to deter anticompetitive conduct by penalizing particular practices. The TPRP Report's recommendation of a Telecommunications Competition Tribunal reflects a belief that ex post enforcement, drawing on competition and communications expertise, would be an effective substitute for CRTC

170. For an elaboration of this "complementary market" perspective on exclusive dealing arrangements, see Timothy Brennan, Saving Section 2: Reframing U.S. Monopolization Law, in THE POLITICAL ECONOMY OF ANTITRUST 417-51 (Vivek Ghosal \& Johan Stennec eds., 2007). 
regulation. ${ }^{171}$ The Order in Council overturning the CRTC's forbearance criteria also reflects a preference for ex post enforcement. ${ }^{172}$ The Bureau's draft Telecommunications Abuse Bulletin outlines how such matters might be adjudicated. ${ }^{173}$

A first aspect of the choice is that antitrust law in Canada and the U.S. does not treat unilateral price setting as a matter for prosecution. ${ }^{174}$ To the extent that one is concerned with a firm setting a monopoly price, the only option is regulation-recognizing, of course, that regulation has its costs as well. The same problem plagues some possible ex post interventions. One might determine that some practices, e.g., discriminatory access or tying, violated competition law. The most relevant examples in this context are contentions that an ILEC monopolized a related market by denying access to an "essential facility." Improving economic performance in those markets will inevitably require setting access prices; otherwise, the firm could exploit most or all of its market power by setting a nondiscriminatory monopoly access price. ${ }^{175}$

A second concern in Canada involves the deterrent effects of ex post enforcement. Under Canadian competition law, abuse of dominance is subject only to injunctive relief. Private parties can bring abuse cases but, unlike in the United States, they cannot collect damages for harm. Recognizing this, Canada's Minister of Industry recommended on December 7, 2006, shortly before proposing to overturn the CRTC forbearance decision, that Parliament amend the Competition Act to provide for up to $\$ 15$ million in administrative monetary penalties ("AMPs") for violations by telecommunications companies. To my knowledge, the Competition Act has not yet been amended to allow for AMPs in this sector. ${ }^{176}$

\section{J. Regulated Conduct}

In its draft Telecommunications Abuse Bulletin, the Bureau took the position that it would not enforce the Competition Act when activities

171. TPRP Report, supra note 11.

172. Local Variance, supra note 10.

173. Telecomm. Abuse Bulletin, supra note 13.

174. U.S. v. Colgate, 250 U.S. 300 (1919). ("In the absence of any purpose to create or maintain a monopoly, the act does not restrict the long recognized right of trader or manufacturer engaged in an entirely private business, freely to exercise his own independent discretion as to parties with whom he will deal; and, of course, he may announce in advance the circumstances under which he will refuse to sell."). Id at 307.

175. Timothy Brennan, Do Easy Cases Make Bad Law? Antitrust Innovations or Missed Opportunities in U.S. v. Microsoft, 69 GEO. WASH. L. R. 1042, 1082 (2001).

176. Bernier, supra note 8 . In 2005 , the Bureau proposed amendments to the Competition Act that would institute AMPs for abuse of dominance generally. This proposal was not enacted before the dissolution of Parliament prior to the election in January 2006. 
involving access to regulated facilities impeded competition. Recently, Dennis Carlton suggested that limiting the role of antitrust in regulated sectors is a desirable division of policy labor. ${ }^{177}$ This position is consistent with that taken by the U.S. Supreme Court in Trinko, which stated that the costs of requirements to deal with competitors exceed the benefits when a regulator is in place to oversee competition. ${ }^{178}$

This standpoint is reflected in Canadian competition policy. The Bureau stated in its June 2006 Bulletin on Regulated Conduct that it would enforce the Competition Act in regulated industries:

[W] here Parliament has articulated an intention to displace competition law enforcement by establishing a comprehensive regulatory regime and providing a regulator the authority to itself take, or to authorize another to take, action inconsistent with the Act, provided the regulator has exercised its regulatory authority in respect of the conduct in question. ${ }^{179}$

As CRTC authority falls under "a comprehensive regulatory scheme" enacted by Parliament, this view is repeated in the Bureau's draft Telecommunications Abuse Bulletin with regard to access to regulated telecommunications facilities. ${ }^{180}$

The difficulty with this position is that the actions under regulatory authority may impede competition in unregulated markets, which may not be under the regulator's purview. The antitrust case leading to the divestiture of AT\&T was predicated on a theory that antitrust law can and should provide structural remedies to anticompetitive conduct by regulated firms, when such conduct leads to the monopolization of unregulated markets. ${ }^{181}$ It remains to be seen whether its competition policy interests are better served by deferring to regulators. At best, the regulators are likely to be more concerned with promoting the public interest in the sectors that remain regulated rather in those it has elected to deregulate (or never regulated in the first place. At worst, they may be unduly influenced by the firms they are nominally assigned to regulate. ${ }^{182}$ We have had roughly a quarter century of U.S. telecommunications experience since the break-up of AT\&T as one part of the experiment. Whether this change in the law represented by Trinko and the Bureau's view of the "Regulated

177. Dennis Carlton \& Randal Picker, Antitrust and Regulation, (Univ. of Chicago Law \& Econ., Olin Working Paper No. 312, 2006), available at http://ssm.com/abstract=937020.

178. Verizon v. Trinko, 540 U.S. 398 (2004).

179. Competition Bureau, Technical Bulletin on 'Regulated' Conduct, June 2006, available at http://www.competitionbureau.gc.ca/PDFs/final_rcdbulletin_e.pdf.

180. Telecomm. Abuse Bulletin, supra note 13, at n.7.

181. Timothy Brennan, Trinko v. Baxter: The Demise of U.S. v. AT\&T, 50 ANTITRUST BULLETIN 634, 664 (2006).

182. George Stigler, The Theory of Economic Regulation, 2 BELL J. ECON. \& MANAGMEMENT SCIENCE 3 (1971). 
Conduct Doctrine" produces similar benefits over the next twenty-five years remains to be seen.

\section{CONCLUSION}

The Canadian telecommunications sector, including industry participants (ILECs, cable providers, stand-alone retail service companies), market observers, regulators, competition enforcers, and the top levels of government, have engaged in a complex and protracted exercise over the last two years to determine whether, how, when, and under what conditions the last regulated telecommunications service, local voice service, should be deregulated. For regulatory policy analysts and decision makers, the Canadian experience provides useful lessons in how the deregulation can be approached. The fruitfulness of the lessons is enhanced by a variety of factors. Canada is geographically proximate to the U.S., with roughly comparable per capita incomes and an almost identical urban/rural population split, and a leading trade partner. Although smaller in population than the U.S., it still has a population comparable to that of California. $^{183}$

Perhaps most important, Canada's overall policy objectives, including adoption of competition as a policy norm, is very similar to that in the U.S. The similarity of ends makes the comparison of means-different policies, legal structures, and implementation-potentially insightful. In this and other areas, U.S. analysts and policymakers may be able to learn a great deal by looking at the Canadian experience.

183. In 2001, Statistics Canada reported an urban/rural split of $80 / 20$. Comparable figures for the U.S. in the 2000 Census were $79 / 21$. 
